\title{
Incentivizing OER Adoption with Course Development Mini-Grants
}

\author{
M. H. Albro \\ Aaron W. Dobbs \\ Michelle T. Foreman \\ Shippensburg University
}

Abstract: Open Educational Resources (OER) are one form of digital scholarship used across the country to make education more accessible to students by removing barriers to essential course materials (such as textbooks and supplementary readings). This case shows how one university has taken steps to increase the prominence of OER in classrooms on campus while engaging in a statewide pilot project.

Keywords: open education, open educational resource, oer, grant program

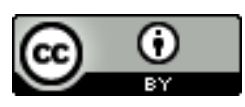

This is an Open Access article distributed under the terms of the Creative Commons Attribution 4.0 International License (http://creativecommons.org/licenses/by/4.0), which permits unrestricted use, distribution, and reproduction in any medium, provided the original work is properly cited. 
"Many observers find it baffling that faculty in higher education have been slow to adopt open educational resources (OER)" (Doan, 2017, p. 665). College textbook costs are rising seemingly in step with tuition and students seem to be less inclined to purchase assigned or required textbooks due to cost barriers. Have we hit "Peak Textbook?" Scholars and some publishers increasingly seem to be interested in providing freely available or lower-cost options for students.

The idea behind Open Educational Resources (OER) and Open Access Textbooks (OAT), that educational materials should be made available at no cost to the learner, has been around for decades. With the commercialization of the Internet, delivery channels for educational materials have multiplied and costs have significantly decreased. Drastic increases in textbook and supplemental materials costs (Okamoto, 2013) are generating a perfect storm of interest in textbook alternatives.

Academic libraries are feeling the impact of increased costs for educational materials and have been active partners in OER efforts since at least 1997, with the founding of MERLOT (www.merlot.org). Allen, Bell, and Billings (2014) urge library involvement in the creation, adoption, and distribution of more-affordable educational materials to increase support for alternative curriculum delivery methods to students, at potentially significant savings. The benefits of OER seem obvious, though Allen et al. (2014) do highlight that implementation challenges seem understated when adapting courses for OER.

\section{Students and Textbooks}

Textbooks and supplementary materials are increasing in cost, often leading students to have to decide between purchasing these materials and meeting other expenses. Over sixty percent of comments in a Florida survey about textbook and course materials costs asserted that the high cost of textbooks resulted in students choosing not to buy the textbook (FLVC, 2018). Similarly, Meyer (2016) found over sixty percent of students reported the cost of a textbook led them to not purchase it. Senack (2014) found that nearly all students who opt out of purchasing a textbook do so with concern 
that this choice will hurt their course grade. He also found that reducing barriers to accessing course materials may help students succeed. Eighty-two percent (82\%) of Senack's (2014) student respondents answered that they would do "significantly better" in a course if the textbook was offered free online. All in all, Senack found three things: 1. students, though concerned for their grades, are put off from purchasing course materials due to high textbook costs; 2. "high textbook costs have ripple effects on other academic decisions" (p. 11); and 3. students believe that free alternatives to traditional textbooks, such as online materials, would improve their academic performance (Senack, 2014).

To act upon these findings, Senack (2014) recommends OER should be embraced on all levels of the campus structure. One suggestion is that parties at all levels of the campus structure, from administrator to student, can work as one to create a pilot program for open textbooks. Alongside a pilot program, Senack suggests legislatures at the state and federal level "should invest in the creation and development of more open textbooks" (p. 15). In order to make these recommendations meritorious, the third suggestion is the adaptation of OAT by classroom faculty. Finally, Senack notes the development of a publishing model that produces quality course materials at a low cost for students would be advantageous (Senack, 2014).

Hilton and Laman (2012) describe how, when their community college adapted OER in some sections of a course and used traditional textbooks in other sections, the OER sections scored higher on departmental final examinations, had higher grade point averages, and had higher retention rates. Winitzky-Stephens and Pickavance (2017) note that when OER courses were adapted at Salt Lake City Community College, a small increase in course grades was noted.

In fairness to the student, cost seems to have been a growing factor in choosing whether to purchase an assigned textbook for a decade or more. Students seem to select the most favorable option that fits their short-term needs and means. Allen et al. (2014) state a reality that many in Journal of New Librarianship, 4 (2019) pp. 449-475 10.21173/newlibs/8/1 
academe seem to ignore: students are often not purchasing any of their required or supporting textbooks. They also highlight implied student perceptions regarding the lack of professorial references in class discussions to material from the textbook. Lack of student access to foundational material assigned by the professor impedes progress for students without the textbook (WinitzkyStephens \& Pickavance, 2017; Hilton \& Laman, 2012; Allen et al., 2014; Bell \& Salem, 2017).

\section{Open Educational Resources}

OERS, as noted by UNESCO, are "teaching, learning or research materials that are in the public domain or released with an intellectual property license that allows for free use, adaptation, and distribution" (quoted in Goodsett, Loomis, and Miles 2016, p. 336). One of the most frequently heralded benefits of these materials is their low cost; however, to be truly "open" these educational resources must embrace "free" in the sense of "libre," meaning their adopters are free to adapt, or remix the content. This ability to customize or modify content and, thanks to Creative Commons or similar licenses, republish that content in an online open format can give instructors greater control over their content, with the added feature of rapid update times, to provide the information they feel may be most useful to their students (Hess, Nann, \& Riddle, 2016).

\section{OER and Libraries}

Higher education faculty have yet to embrace OER to the fullest potential possible, taking slow steps toward exploring the possibilities available (Doan, 2017). Smith and Lee (2016) note libraries hold a place on campuses where they can advocate for the adoption and production of OER, as their employees are known to be masters of finding, evaluating, and organizing information. In addition to their information retrieval and organization skills, libraries have been seen as early adopters of technology, which in part has been brought on by grand changes in Internet and web technology. To 
stay relevant, academic libraries have evolved their services and resources to better meet the needs of their users, particularly in online learning contexts (Smith \& Lee, 2016).

This cumulative knowledge and reputation can be leveraged to effectively speak in favor of OER on academic campuses. As Allen et al. (2014) denote, "many librarians are finding themselves wellsuited to assisting instructors with the OER curation process: helping them find, aggregate, and assess the quality of relevant materials from a broad array of sources" (p. 12). This assistance can offset the intensity many faculty face in migrating from traditional textbooks to OER (Allen et al., 2014).

Libraries, in their role as change agents and forward-looking research advocates, are well positioned to raise awareness and provide impetus and support for textbook affordability initiatives (Bell \& Salem, 2017). The intersection of decreasing public funding support, increasing tuition and materials costs, and declining numbers of traditionally college-aged prospects is rapidly approaching, if not already upon higher education institutions. Libraries must, as Bell and Salem (2017) suggest, articulate the need for textbook affordability initiatives.

\section{OER and Higher Education}

The promise of OER and OAT resides in the availability and discoverability of open-licensed materials that can be adapted to the needs of each individual professor. Long-established repositories, such as MERLOT and MIT's OpenCourseWare (OCW) (ocw.mit.edu), and more recent efforts, such as those provided by members of the Open Textbook Network (research.cehd.umn.edu/otn), provide access to polished materials for instructors wanting a plug-and-play style textbook. These same sources, along with many others, provide a rich tapestry of materials supporting more home-grown DIY efforts for instructors wanting to customize and tailor experiences for their students.

With the proliferation of OER repositories, comprehensive discoverability of resources can be challenging. Enhancing common commercial general Internet searches, the Mason OER Metafinder 
(MOM, oer.deepwebaccess.com/oer/desktop/en/search.html) offers a deep search of resources found in OER-specific sites as well as through digital libraries. The search filters provide a sense of familiarity for those accustomed to library searches, and the visual narrowing feature allows for intuitive topic honing.

Higher education institutions are responding to these increasingly acute challenges. Many institutions are at least dabbling with pilots projects to reduce the financial burden of textbooks. The OER environment is growing toward maturity; however, as Allen et al. (2014) highlight, redesigning a course, moving from the traditional textbook to using only OER materials is a challenging prospect. Academic librarians are resourceful partners for discovering and organizing relevant available resources. One way to encourage professors to redesign courses is to incentivize their effort. Grant funding is available for large scale incentivization, such as the SUNY Open Textbooks program (textbooks.opensuny.org). A variety of existing OER projects and incentivization models are listed in the SPARC Connect OER directory (connect.sparcopen.org/directory). Pitcher (2017) describes this pilot program which incentivizes faculty to publish within their expertise and then peer-reviews and published their work online via Open Monograph Press (pkp.sfu.ca/omp).

\section{OER Incentivization at Shippensburg University}

Librarians and the administration of the Ezra Lehman Memorial Library proposed creation of a mini-grant program to incentivize university faculty to adapt their courses to be free of any additional costs to students. The Provost's Office accepted and implemented the proposal, creating the OER MiniGrant program, which would provide participating faculty with an award of $\$ 500$, an amount consistent with similar awards offered from the University Provost's office, for faculty who remove traditional textbooks and supplementary materials from a course and replace them with open educational resources. Concurrently, the library deans and directors of the Pennsylvania State System of Higher 
Education proposed and received approval of a pilot project encouraging OER exploration at ten state universities.

Faculty who would participate in the OER Mini-grant program would be assigned a personal librarian who could aid in the identification and adaptation of OER. At the completion of the semester, participating faculty would be required to engage in an assessment of the OER implementation process. Through this and future programs, we hope to reduce financial barriers to education for students. By increasing the prevalence of open scholarship on campus, we are acting to improve access to scholarship and student success.

\section{Institutional Context}

The Pennsylvania State System of Higher Education (PASSHE) was established in 1983 as a state-wide consortium of 14 universities that date back to the 19th century. Collectively, PASSHE serves about 97,000 students and employs more than 12,000 faculty and staff.

In early 2017, a group of library deans and directors within the State System of Higher Education Library Council (SSHELCO) began meeting to explore ways to support and facilitate the adoption of OERs on campuses at Pennsylvania State System universities. This led to outreach during that fall to the chief academic officers of the state system for this purpose, which progressed to the development of a pilot program within PASSHE. This multi-phase pilot project focused on introducing the use of OERs in courses at participating universities.

In Phase 1 (Fall 2017), each PASSHE university that had committed to participation in the pilot would determine the most appropriate method and level of implementation for its location. Each university's library dean or director would determine how library faculty would participate and in what numbers. In Phase 2 (Spring and Summer 2018) faculty at participating universities would identify and select OERs for incorporation into courses for the Fall 2018 semester. In Phase 3 (Fall 2018), the courses 
would be implemented with the new OERs. In Phase 4 (Spring 2019), all assessment and evaluation of the pilot project, through surveys, focus groups, or interviews, of both students and faculty, would be completed. The development of this state-wide pilot project occurred concurrently with Shippensburg University's OER Mini-grant Program, allowing the two to dovetail together in a shared timeline. Shippensburg University (Ship) was founded in 1871 and is a member of PASSHE. With a student-faculty ratio of 20 -to-1 personalized attention is the norm for its students. Students have access to unique resources, such as the Center for Land Use and Sustainability, a stock trading room, centers for entrepreneurial leadership and innovation, a fashion archives and museum, and the only public elementary lab school in the state. Ship recently redesigned its general education program, added an entry year experience course, and has focused interest on lowering course-related materials costs.

\section{OER Mini-grants Program Development}

Beginning in 2016-17, the Student Success Team at Shippensburg University directed attention toward financial barriers to student success, including access to textbooks. This impetus led representatives from Ezra Lehman Memorial Library and the School of Academic Programs \& Services to discuss ways the library could reduce barriers to textbook access for students, germinating the concept for OER opportunities and incentives for faculty.

Course redesign can be time-intensive when eliminating textbook and supplemental resource cost for students, and we realized we wanted to facilitate not only training and encouragement, but also some remuneration for effort and commitment. In past semesters, awards had been offered to faculty by the Provost's Office in recognition of various programs or innovations. This inspired the idea of proposing a mini-grant for the adoption of open educational resources. 


\section{Program Proposal}

Library faculty and administration took the lead on developing the proposal, outlining the content and completing a brief literature review to increase credibility for the target audience. They met with the School of Academic Programs and Services throughout the process to ensure the proposal document continued to meet all original goals: reducing barriers to course materials, and integrating assessment from students and faculty. An internal goal was to conclude the evaluation process with recommendations for future action. In February, 2018, after all parties were content with the proposal, it was submitted to the provost for review (see Appendices A-D).

In the area of the proposal dedicated to reducing barriers to course materials, participating faculty were required to design a course where materials were available at no cost to enrolled students (see Appendix B). There were no other limitations on these resources, which could include library resources, open educational resources available in OER repositories, or resources of faculty's own creation, for example. In the assessment component of the proposal, participating faculty were required to complete an assessment of their experience adopting materials for the course (see Appendix C). Faculty were also required to have their students complete a survey (see Appendix D) about how OER impacted their course experience, with a focus on their frequency of use and the perceived quality of the course materials. Upon completion and submission of the assessment measures, faculty would receive their stipends. At this time, program designers could review the data to evaluate the success of the program and make recommendations for the future. 


\section{Proposal Implementation}

The proposal was accepted for implementation. In April, 2018, the Shippensburg University Provost's Office announced the OER mini-grant program to faculty via email. Interested faculty submitted the name of the fall course for which they would utilize OER and no-cost resources, the estimated number of students impacted, and other related comments to the coordinators. All information was provided through the university's application system by a May 1 deadline. In the email, faculty were encouraged to discuss the pilot project with either of the librarians who assist with the program for assistance in location and evaluation of OER textbooks and other materials.

Four Shippensburg faculty members reached out to the librarians on the OER team prior to the application deadline. The librarians provided these faculty with resources focused upon the specific courses in which faculty were interested in using OER. These resources included basic information on OERs: what they are and how they can be used in a university setting, links to specific OAT, and links to OER repositories, such as the Open Textbook Library (open.umn.edu/opentextbooks), OER Commons (www.oercommons.org), and OpenStax (openstax.org).

Eight faculty members from across the university curricula applied to participate in the initial mini-grant program cohort, revising a total of ten courses. Each faculty member was invited to work with a librarian to locate OER materials or textbooks, only one professor chose to collaborate. The courses adapted for OER content were conducted in Fall 2018, and assessments of faculty and students occurred at the end of the semester and were shared with the team in Spring 2019. Assessment data gathered via forms shown in Appendix C and Appendix D will be used to measure student impact and will inform conversations about OER and student success efforts at Shippensburg University. 


\section{Data Analysis and Results}

Qualitative responses from all participants were coded using grounded theory (Strauss \& Corbin, 1990). To avoid preconceived opinions, the results-coding process was used to develop categories to effectively explore and analyze the data. Student OER experience survey responses [ $n=529]$ were coded using NVivo, resulting in 13 categories sharing general remarks and positive or negative impacts from students' OER experience. Faculty OER experience survey responses [n=7] were coded in fiveprint, resulting in five categories describing faculty experiences with OER materials and faculty perceptions of the student OER experience.

\section{Student Responses}

More than half of student positive impact responses [n=145, 100\%] described from the OER student survey mentioned Cost [94, 64\%] and Content [70, 48\%]. Other common positive response categories were Accessibility of the resource [49, 33\%], Ease of use [22, 15\%] and Types of sources [20, $13 \%]$.

Almost one-third of student negative impact responses [n=148, 100\%], amusingly, used phrases similar to "nothing negative to say" [44, 30\%]. Negative impacts were reported in the following categories: Content [35, 23\%], Ease of use $[20,13 \%]$ and then a range of academic processes that were not related to OER $[17,11 \%]$.

Students were invited to leave final comments [n=35, 100\%] about their experiences with OER in their course. Almost half $[14,45 \%]$ of the final comments were students noting they were happy with their OER experience. Cost [11, 31\%] was once again a common category. A breakdown of student comments by category and case can be seen in Table 1 . 


\section{Faculty Responses}

Faculty responses were particularly rich and contextual, covering student preparedness, cost, quality of content, perceived student stress, and student engagement. Faculty [ $n=7]$ reported these perceptions about their students' experience in their pilot course compared to previous iterations of the course:

- Student preparedness levels either showed no change [3], showed minor improvements [1], or showed major improvement [3];

- OER textbook and course materials resulted in student savings [7];

- Faculty perceived textbook content to be higher quality [1], similar [5], or lower quality [1] ;

- Faculty perceived student stress levels showed decreased levels of stress [6] or no change [1];

- Faculty perceived student engagement improvement [5] or remained similar [2].

\section{Discussion}

Faculty and student responses in this study agree with current OER literature in higher education. Faculty noted that more students had access to materials from the beginning of the course than they did in non-OER courses and also observed student comments about buying or not buying textbooks in their other, non-OER courses. This supports the Allen et al. (2014) findings that students frequently do not purchase their required textbooks. Faculty also noted the need to supplement their OER of choice with other content, such as videos, and mentioned the need to create their own teaching apparatus or course pack to make the course run smoothly. This is consistent with the challenges Allen and colleagues present in relation to redesigning a course and moving from a traditional textbook to only OER materials (2014). Overall, the faculty assessment responses support the notion that academic 
progress in a course is impeded when students lack access to assigned foundational materials (Winitzky-Stephens \& Pickavance, 2017; Hilton \& Laman, 2012; Allen et al., 2014; Bell \& Salem, 2017).

Student assessment responses in this study supported the results described in Senack (2014) and the Florida Virtual Campus (FLVC) Office of Distance Learning and Student Services (2018). A large portion of the comments provided highlighted cost savings and convenience of OER. Students also noted the increased integration of OER textbook content into class lectures and discussions, mirroring the reports of Allen et al. (2014). On the whole, student and faculty responses fell into five major categories: student preparedness, cost, quality of content, perceived student stress relating to course materials, and student engagement with course materials.

\section{Student Preparedness}

Improvements to student preparedness was reported as mixed. About half of the faculty participants reported minor to no improvements in preparedness, noting that even with the freely available textbook their students seemed not to be reading the assigned sections. Faculty reporting an improvement in student preparedness noted that preparedness noticeably improved earlier in the semester and attributed this not having to purchase the textbook.

Student comments, such as "The fact that there was no more cost of a textbook was phenomenal, and I feel as though I got more out of the class since the professor was very well-versed in his own material provided to us," and "The number one best thing is that I didn't have to spend lots of money on a textbook that has a lot of information in it that we aren't even going to cover or barely mention. Another good thing about it is we focus on the most important information that my professor 
gives. Lastly, it is good because it makes do better on exams and assignments because I have less information to focus on" seem to support these assertions.

\section{Cost}

Nearly all faculty noted student gratefulness over the cost savings that OER offered and textbook cost was the primary focus of student comments. The average cost of course materials prior to the OER program was $\$ 97.50$, with a range in costs from $\$ 35.99$ to $\$ 150$. In all OER pilot courses, the cost of course materials was $\$ 0$, showing an average savings of nearly $\$ 100$ per course.

Student comments include "More professors should do this due to the insane cost of textbooks and access codes" and "LOVE IT. Please continue doing this as it saves students so much money and really allows the professor to focus on the important concepts."

\section{Quality of Content}

One professor noted an improvement in the quality of the content, mentioning that the materials could be tailored to the class without superfluous information, making it easier for students to navigate. The remaining professors said the quality of the content was equal, but they found it more difficult to find quality material for free. Another wished it came with an instructor course pack, but noted that once they created a "teaching apparatus" themselves, the content was good. Another noted they found it necessary to supplement their OER text with videos to fill in content gaps, but once they did that they felt the quality was equal.

Students shared their observations about content quality, some noting that "Traditional course texts include many bells and whistles that are likely not necessary. I find that I am distracted by all the side notes and additional unneeded info cluttered throughout traditional textbooks." Others 
shared that "There is nothing bad about OER. It's brilliant. It allows instructors to create a "textbook" specific to what THEY want to teach. Instead of having to try to find a book that covers what they want." Overall, students seemed to appreciate the zero out of pocket costs and the tailored content designed to fit the course.

\section{Perceived Student Stress Relating to Course Materials}

In general, faculty perception of student stress decreased with the use of OER. Of particular note is one professor's comment that prior to the implementation of OER, students would not have their textbook for weeks, even if a copy was on reserve at the library. This professor noted that this always led to starting the semester with high stress that continued as students struggled to catch up from that time without the book. This professor noted that after implementing OER they were more aware of students complaining about buying textbooks they used infrequently or about the cost of online access codes in other courses. Nearly all professors noted that students seemed less stressed out after the implementation of OER, which faculty inferred to stem from earlier interaction with the materials or feeling adequately prepared for the class.

Students mentioned reduced stress relating increased interest such as “...the material was for more engaging and interesting, and it was overall less discouraging and stressful". A few students did comment about wanting a physical item in which to take notes and one seemed to blame OER for not meeting standard educational processes, "If I don't understand something I have to go to office hours for clarification." 


\section{Student Engagement with Course Materials}

Most courses showed improvements in student engagement with course materials as

measured by the instructor; two courses showed no change from an already high level of engagement. Interestingly, one instructor noted that they believed students missed more assignments with the OER model due to the online platform that was used, specifically saying that students had trouble remembering how to access the material. Another instructor noted that while engagement was up, keeping materials organized (in relation to printed handouts) became more complex as the semester went along. On a positive note, one professor said, "Class participation based on these exercises improved markedly. Weaker students responded to certain ... units, which helped draw them more deeply into [the subject]."

Some student respondents shared similar comments, such as " 1 . [the OER textbook] is online, and I would rather a physical copy of something in my hand; 2 . sometimes it can be difficult to navigate; 3. I forgot about it because it wasn't a physical thing, once I closed the page it was gone and out of mind;" however, most comments expressed more-positive sentiments, such as "I can see it at anytime, it is not extra money, and it updates day after day."

\section{Conclusions}

As the OER mini-grant program progresses, assessment information will be used to inform future OER endeavors at Shippensburg University with the hope of building a community of practice surrounding OER at the campus level. Following in the steps of Wenger et al., the librarians at Shippensburg University hope to evolve the mini-grant program into a community of practice that establishes the library as the campus hub for OER. This mini-grant program is at the beginning of the process. Following the recommendations of Smith \& Lee (2016), maturation and continual stewardship 
toward the campus will be necessary to establish boundaries and develop a strong role in the faculty community.

In addition to establishing a community of practice on the Shippensburg University campus, an area for future growth is a broader initiative to promote OER and textbook affordability movements in academic institutions across the state. The Pennsylvania Academic Library Consortium (PALCI) Affordable Learning PA project (palci.org/alpa-about) is a good example of statewide efforts supporting OER promotion. This and related efforts will serve well in a future where we anticipate further decreases in higher education funding at the state level and declines in enrollment nationally. Librarians are situated in a good position to advocate for textbook affordability measures while educating faculty and institutional administrators on alternatives to traditional course materials (Bell \& Salem, 2017).

Faculty and students at Shippensburg University mirrored the main findings from the higher education OER literature. Faculty generally appreciated improvements in student preparation while finding some challenges in locating or adapting relevant textbooks and supplemental materials. Students were enthused with the cost and convenience of the course textbook and appreciated faculty engagement with the textbook material.

Based on the student and faculty data and feedback described above, the library will propose continuing the OER Mini-grant program in the next academic year, focusing on Spring semester courses for the second iteration.

The process of engaging faculty with this mini-grant program demonstrated a need for increased awareness of what an OER is and how the use and access of these resources could work in a classroom environment. In conversations with faculty, it was found that there is a general desire for a turnkey-solution approach, though there is a willingness to cobble together multiple sources if 
necessary. Incentivizing course conversion starts a process of advocacy and dialog that highlights an ongoing commitment to reducing student costs. This passion may last long beyond incentive availability.

\section{References}

Allen, N., Bell, S., \& Billings, M. (2014). Spreading the word, building a community: Vision for a national librarian OER movement. Against the Grain, 26 (5), 1-12. https://doi.org/10.7771/2380176X.6842.

Bell, S. J., \& Salem, J. A. (2017). It's up to the librarians: Establishing a statewide OER initiative. Pennsylvania Libraries: Research and Practice, 5(2), 77-82. https://doi.org/10.5195/palrap.2017.166.

Doan, T. (2017). Why not OER? portal: Libraries and the Academy, 17(4), 665-669. https://doi.org/10.1353/pla.2017.0039.

Florida Virtual Campus (FLVC) Office of Distance Learning and Student Services. (2018). Report: 2018 Student Textbook and Course Materials Survey. Retrieved from https://dlss.flvc.org/documents/210036/1314923/2018+Student+Textbook+and+Course+Materi als+Survey+Report+--+FINAL+VERSION+--+20190308.pdf/07478d85-89c2-3742-209a$9 \mathrm{cc5} d f 8 c d 7$ ea.

Goodsett, M., Loomis, B., \& Miles, M. (2016). The more we work together: Leading campus OER initiatives through library-faculty collaboration. College \& Undergraduate Libraries, 23(3), 335342. https://doi.org/10.1080/10691316.2016.1206328.

Hess, J. I., Nann, A. J., \& Riddle, K. E. (2016). Navigating OER: The library's role in bringing OER to campus. The Serials Librarian, 70(1-4), 128-134. https://doi.org/10.1080/0361526X.2016.1153326. 
Hilton, J., \& Laman, C. (2012). One college's use of an open psychology textbook. Open Learning, 27(3), 265-272. https://doi.org/10.1080/02680513.2012.716657.

Meyer, L. (2016). Report: Students shun new textbooks to reduce education expenses. Campus Technology. Retrieved from https://campustechnology.com/articles/2016/08/24/reportstudents-shun-new-textbooks-to-reduce-education-expenses.aspx.

Okamoto, K. (2013). Making higher education more affordable, one course reading at a time: Academic libraries as key advocates for open access textbooks and educational resources. CUNY Academic Works. http://academicworks.cuny.edu/jj_pubs/103.

Pitcher, K. (2017). Library publishing of open textbooks: The open SUNY textbooks program. Against the Grain, 26(5), 22-24. https://doi.org/10.7771/2380-176X.6844.

Senack, E. (2014). Report: Fixing the Broken Textbook Market: How Students Respond to High Textbook Costs and Demand Alternatives. DC:The Student PIRGs. http://uspirg.org/sites/pirg/files/reports/NATIONAL\%20Fixing\%20Broken\%20Textbooks\%20Re port1.pdf.

Smith, B., \& Lee, L. (2016). Librarians and OER: Cultivating a community of practice to be more effective advocates. Journal of Library \& Information Services in Distance Learning, 11(1-2), 106-122. http://doi.org/10.1080/1533290X.2016.1226592.

Strauss, A., \& Corbin, J. (1990). Basics of qualitative research. Newbury Park, CA: SAGE Publications. Winitzky-Stephens, J., \& Pickavance, J. (2017). Open educational resources and student course outcomes: A multilevel analysis. International Review of Research in Open and Distributed Learning, 18(4), 35-49. https://eric.ed.gov/contentdelivery/servlet/ERICServlet?accno=EJ1146207. 
Table 1. Numerical and percentage breakdown of student comments by category across cases.

\begin{tabular}{|c|c|c|c|c|c|c|c|c|}
\hline Node & Total & $\begin{array}{c}\% \\
\text { Total }\end{array}$ & Positives & $\begin{array}{c}\% \\
\text { Positives }\end{array}$ & Negatives & $\begin{array}{c}\% \\
\text { Negatives }\end{array}$ & $\begin{array}{c}\text { Final } \\
\text { Remarks }\end{array}$ & $\begin{array}{l}\text { \% Final } \\
\text { Remarks }\end{array}$ \\
\hline Content & 110 & 20.79 & 70 & 23.10 & 35 & 20.00 & 5 & 9.80 \\
\hline Cost & 107 & 20.23 & 94 & 31.02 & 2 & 1.14 & 11 & 21.57 \\
\hline $\begin{array}{l}\text { No } \\
\text { negatives }\end{array}$ & 53 & 10.02 & 0 & 0.00 & 53 & 30.29 & 0 & 0.00 \\
\hline $\begin{array}{l}\text { Ease of } \\
\text { Access }\end{array}$ & 49 & 9.26 & 49 & 16.17 & 0 & 0.00 & 0 & 0.00 \\
\hline Ease of use & 42 & 7.94 & 22 & 7.26 & 20 & 11.43 & 0 & 0.00 \\
\hline $\begin{array}{l}\text { Type of } \\
\text { sources }\end{array}$ & 38 & 7.18 & 20 & 6.60 & 13 & 7.43 & 5 & 9.80 \\
\hline $\begin{array}{l}\text { Not OER } \\
\text { related }\end{array}$ & 29 & 5.48 & 11 & 3.63 & 17 & 9.71 & 1 & 1.96 \\
\hline $\begin{array}{l}\text { Instructor } \\
\text { interaction }\end{array}$ & 27 & 5.10 & 15 & 4.95 & 7 & 4.00 & 5 & 9.80 \\
\hline Happy & 23 & 4.35 & 0 & 0.00 & 0 & 0.00 & 23 & 45.10 \\
\hline Usefulness & 21 & 3.97 & 16 & 5.28 & 5 & 2.86 & 0 & 0.00 \\
\hline Internet & 13 & 2.46 & 2 & 0.66 & 10 & 5.71 & 1 & 1.96 \\
\hline Printing & 13 & 2.46 & 2 & 0.66 & 11 & 6.29 & 0 & 0.00 \\
\hline Time & 4 & 0.76 & 2 & 0.66 & 2 & 1.14 & 0 & 0.00 \\
\hline Total & 529 & 100 & 303 & 100 & 175 & 100 & 51 & 100 \\
\hline
\end{tabular}




\section{Appendix A: Open Educational Resources (OER) Mini-grant Application}

Purpose: Textbooks and supplementary materials are increasing in cost, often leading students to have to decide between purchasing these materials and meeting other expenses.

- A recent student survey has shown that "nearly 66 percent of students have opted out of buying a textbook due to the cost" (Meyer 2016, para. 4).

- " $94 \%$ of students who had foregone purchasing a textbook were concerned that doing so would hurt their grade in a course.

- More than half of the students felt significant concern for their grade" (Senack 2014, 11). OER are freely accessible, openly licensed text, media, and other digital assets that are used for teaching, learning, and research. They provide a solution for these concerns and show great potential if utilized in course development.

At Shippensburg University’s Student Success Team Meeting in June, 2017, Dr. Jennifer Haughie shared information regarding the financial barrier to paying for college many students face: $\$ 23,840$ Direct Costs per Academic Year (based on Basic B Suite housing) \$5920 Full Pell (EFC under \$5000)

\$3674 Full State Grant $\$ 5500$ Freshman Loans

\$4000 Freshman Loan with Parent Plus Loan Denial \$8746 Gap per AY in paying their bill (Doesn't factor in books and indirect costs, like transportation, etc.)

The Financial Aid Office factors in $\$ 4,458$ in indirect costs as well, bringing the total financial gap for many students to $\$ 13,204$. The university endeavors to offset these costs through the tuition grant pilot, last dollar financial aid, and the housing grant program. Additionally, scholarships may be 
available. Any means to shrink this gap benefits our students.

Reducing barriers to accessing course materials by offering courses with no additional expenses beyond tuition and fees may help students succeed. Initiatives in this area have the potential to boost both student performance.

- $82 \%$ of students said they would do "significantly better" in a course if the textbook was offered free online (Senack 2014).

- When one community college adapted OER in some sections of a course and used traditional textbooks in other sections, they determined that the OER sections scored higher on departmental final examinations, had higher grade point averages, and had higher retention rates (Hilton \& Laman, 2012).

- When OER courses were adapted at Salt Lake City Community College, a small increase in course grades was noted (Winitzky-Stephens \& Pickavance, 2017).

Faculty who volunteer to revise their syllabi around these existing resources would receive a mini grant (up to \$500) provided by the Provost’s Office. Additionally, in his or her role as an information professional, a librarian would be assigned and available to assist the faculty member in selecting OERs, and other resources freely available to students, through the revision process.

\section{PASSHE Initiative Background.}

In November of 2017, information was shared with the PASSHE Chief Academic Officers, as recommendations from the SSHELCO Deans and Directors for a System-wide Pilot Project on introducing the use of Open Educational Resources. This resulted in a state-wide pilot in multiple phases.

- Phase 1 (Fall 2017)

University libraries determine number of librarians assigned to support the pilot project. 
- $\quad$ Phase 2 (Spring \& Summer 2018)

Universities determine the number of faculty and courses that will participate in the pilot.

- $\quad$ Phase 3 (Fall 2018)

Implementation/execution of the Pilot project.

- $\quad$ Phase 4 (Spring 2019)

Assessment and evaluation of the Pilot project.

\section{References}

Hilton, J., \& Laman, C. (2012). One college's use of an open psychology textbook. Open Learning, 27(3), 265-272. https://doi.org/10.1080/02680513.2012.716657.

Meyer, L. (2016). Report: Students shun new textbooks to reduce education expenses. Campus Technology. Retrieved from https://campustechnology.com/articles/2016/08/24/reportstudents-shun-new-textbooks-to-reduce-education-expenses.aspx.

Senack, Ethan. 2014. Report: Fixing the Broken Textbook Market: How Students Respond to High Textbook Costs and Demand Alternatives. DC:The Student PIRGs. http://uspirg.org/sites/pirg/files/reports/NATIONAL\%20Fixing\%20Broken\%20Textbooks\%20Re port1.pdf.

Winitzky-Stephens, J., \& Pickavance, J. (2017). Open educational resources and student course outcomes: A multilevel analysis. International Review of Research in Open and Distributed Learning, 18(4), 35-49. https://eric.ed.gov/contentdelivery/servlet/ERICServlet?accno=EJ1146207. 


\section{Appendix B: Teaching Mini-grant Requirements}

Requirements for the Mini-grant:

- The revised course syllabus must not require students to purchase any supplemental texts.

- The faculty member will adopt an OER textbook or other OER materials as primary texts for the course.

- All supplemental course materials must be freely available to the students (through the use of library resources, e-reserves, links, or other means).

- The participating faculty member will assess and report back on the experience. Grant funds will be dispersed after completion of assessment.

- The faculty member will complete a pre-developed, reflective survey about his or her experience adopting OER materials for his or her course.

- The faculty member will have his or her students complete a pre-developed survey about how OER impacted their course experience: http://ship.libsurveys.com/studentoer.

\section{Application Process}

Faculty will submit the name of the course they will be teaching in the fall, for which they will replace a traditional textbook with an OER, pending selection. The estimated number of students impacted should also be included. Applicants are encouraged to discuss the pilot project with either of the project librarians prior to application: Prof. Maggie Albro or Prof. Aaron Dobbs.

\section{Timeline.}

Spring 2018: Proposal approval. Advertising.

Application deadline for participants.

Assignment of personal librarian. 
Scheduling of support meetings as needed to select OER resources to plan implementation.

Fall $2018 \quad$ Course Implementation

Spring 2018 Assessment 


\section{Appendix C: Teaching Mini-grant Report Template}

Adoption of Open Educational Resources (OER) in Courses

Instructor's Name:

Course:

\begin{tabular}{|l|l|l|l|}
\hline & $\begin{array}{l}\text { Prior to adoption of } \\
\text { OER }\end{array}$ & $\begin{array}{l}\text { After the adoption } \\
\text { of OER }\end{array}$ & Evidence \\
\hline $\begin{array}{l}\text { Student preparedness for class } \\
\text { (completion of assigned readings, } \\
\text { activities, etc.) }\end{array}$ & & & \\
\hline $\begin{array}{l}\text { Cost to students for course materials } \\
\text { Students }\end{array}$ & & & \\
\hline $\begin{array}{l}\text { Perceived student stress relating to } \\
\text { the course materials }\end{array}$ & & & \\
\hline $\begin{array}{l}\text { Student engagement with the course } \\
\text { materials presented outside of class }\end{array}$ & & & \\
\hline
\end{tabular}




\section{Appendix D: OER \& Student Course Experience Survey}

Please take a few moments to complete this survey about your experience with Open Educational Resources (OER) in your course.

According to the OER Commons, Open Educational Resources are, "Open Educational Resources are teaching and learning materials that you may freely use and reuse, without charge."

1. How often did you use the course materials?

- Every day

- A few times a week

- Weekly

- Monthly

- I did not use the course materials.

2. Please rate the quality of the course materials used. For reference, think of the quality of a textbook you have used in other courses.

- Very low quality

- Low quality

- Average quality

- High quality

- Very high quality

3. What are the three best things (and why) about the use of OER in your course?

4. What are the three worst things (and why) about the use of OER in your course?

5. What kind of materials would you prefer be required in the courses you take? 
- I prefer a traditional textbook

- I prefer smaller books or nontraditional textbooks

- I prefer open educational resources

- Other:

6. Is there anything else you would like to share about your experience with OER in your course? 